DOI 10. 18307/2020. 0501

(c) 2020 by Journal of Lake Sciences

\title{
浅水湖泊湖沼学与太湖富营养化控制研究
}

\author{
秦伯强** \\ (中国科学院南京地理与湖泊研究所,南京 210008)
}

\begin{abstract}
摘 要: 自 2007 年无锡暴发饮用水危机事件以来,太湖经历了前所未有的高强度、大规模治理,各种治理措施累计投资 已经超过千亿元. 监测显示, 在治理初期太湖的氮、磷浓度下降明显, 水质有所好转, 但最近几年关键水质指标总磷与浮 游植物叶绿素 $a$ 浓度出现了波动,蓝藻水华有所反弹. 研究表明,太湖的外源负荷并没有减少, 这与城镇用水量增加、污 水排放标准偏低、面源污染削减不足有很大的关系; 同时, 内源负荷也因为蓝藻水华的持续而加重, 浅水湖泊水深浅、扰 动强的特点强化了磷的循环利用效率, 加剧了内源负荷对湖泊富营养化和蓝藻水华的影响. 气候变暖叠加营养盐富集的 复合效应、流域风速下降以及暴雨事件频次和强度增加等气象水文条件变化, 都促进了太湖蓝藻水华的暴发; 蓝藻水华 的时空分布特征则受湖泊水动力的决定性影响. 太湖治理的曲折过程, 凸显了大型浅水湖泊湖沼学研究的不断深人与发 展, 未来需要继续加强多学科交叉研究,特别是基于湖泊一流域系统的气象水文、生物地球化学和生物生态学的学科交 叉. 对于太湖生态环境的综合治理和管理, 既要注重湖泊与流域相结合, 更需要重视自然科学和人文科学的有机融合, 才 能真正达到控制太湖富营养化、维护流域水环境安全与社会经济可持续发展的目标.
\end{abstract}

关键词: 浅水湖泊; 太湖;蓝藻水华;气候变化;富营养化治理;湖沼学

\section{Shallow lake limnology and control of eutrophication in Lake Taihu*}

\author{
QIN Boqiang ** \\ ( Nanjing Institute of Geography and Limnology, Chinese Academy of Sciences, Nanjing 210008, P.R.China)
}

\begin{abstract}
Unprecedented high intensity and large-scale restoration have been conducted in Lake Taihu since 2007 when the water crisis happened in Wuxi, and the cumulative investment of various governance measures has exceeded 100 billion RMB. As the long-term monitoring indicated, the nitrogen and phosphorus concentration in Lake Taihu decreased significantly and the water quality improved during the first few years. However, the water quality fluctuated and cyanobacteria bloom rebounded during the recent years. Studies implied that the external loading of nutrients did not decrease in Lake Taihu, which was largely related to the increase of urban water consumption, low sewage discharge standard and insufficient reduction of non-point source pollution. Meanwhile, the internal loading was aggravated by continuous cyanobacteria blooms. In addition, the impact of internal loading on lake eutrophication and cyanobacteria blooms was hence exacerbated in the case that the characteristics of shallow lakes as small water depth and strong disturbance are in favor of the efficiency of phosphorus cycling and uptake. The intensity and frequency of cyanobacteria blooms, of which the spatial and temporal distribution is determined by lake hydrodynamics, were aggravated by the combined effects of climate warming and nutrient enrichment, and changes in meteorological and hydrological conditions such as the decrease in wind speed over the lake catchment and the increase in the intensity and frequency of rainstorm events. In order to control the eutrophication of Lake Taihu, ensure the water environment security and maintain the sustainable development of society and economy, we should combine the lakes and basins as a whole, and should be conscious of importance to the combination of natural science and technology, the humanities and management.
\end{abstract}

Keywords: Shallow lake; Lake Taihu; cyaonbacterial bloom; climate change; eutrophication management; limnology

* 2020-06-28 收稿; 2020-07-18 收修改稿.

国家自然科学基金创新研究群体项目 (41621002)、国家水体污染控制与治理科技重大专项 (2017ZX07203, 2018ZX07701001-24) 和中国科学院前沿科学重点研究项目 (QYZDJ-SSW-DQC008) 联合资助.

** 通信作者;E-mail:qinbq@ niglas.ac.cn. 
应《湖泊科学》编辑部之约, 我于 2009 年撰写了综述性文章《太湖生态与环境若干问题的研究进展及其 展望》 ${ }^{[1]}$, 发表在《湖泊科学》第 21 卷第 4 期. 至今已经过去 10 个年头了, 这也是太湖富营养化治理不寻常 的 10 年. 2007 年无锡暴发饮用水危机事件之后 ${ }^{[2]}$, 从流域到湖泊启动了大规模的治理行动. 基于在太湖梅 梁湾饮用水水源地开展的系列生态恢复试验 ${ }^{3-4]}$, 我们发现湖泊生态修复 (特别是沉水植物恢复) 必须以降 低藻类生物量、减少悬浮物和提高水体透明度等生境条件的改善为前提 ${ }^{[5-6]}$, 进而提出了太湖水环境治理 “控源截污、环境改善、生态修复” 的战略路线 ${ }^{[5-7]}$, 扭转了当时较为盛行的以湖体生态恢复为核心的富营养 化治理策略 ${ }^{[3]}$, 形成了控源截污是湖泊治理初期必经之路的共识. 因此, 2007 年以来太湖富营养化治理加强 了控源截污工作,包括大规模新建城镇污水处理厂, 大量铺设城市污水管网系统、关闭高污低效企业、治理 大中型规模畜禽养殖场、拆除太湖所有的围网养殖、从长江引水改善水流条件 ${ }^{[8]}$, 以及实施底泥清淤和蓝藻 打捞等内源控制工程, 累计投资逾千亿元. 如果没有上述大规模、高强度的投人与治理, 在近 10 年太湖地区 国民生产总值增加近 2 倍、用水量增加 50\% 80\% 的情况下, 无法想象如今太湖的水环境状况, 富营养化与 蓝藻水华灾害将如何泛滥.

中国科学院太湖湖泊生态系统研究站 (下文简称“太湖站”) 的长期监测数据显示, 2007-2013 年期间, 全湖的总氮、总磷浓度均趋于下降 ${ }^{[9-10]}$, 富营养化与蓝藻水华的发展势头得到了初步遏制. 但是, 2014 年以 后, 特别是 2016 年以来, 太湖总磷浓度开始波动反弹, 蓝藻水华呈现扩大趋势 ${ }^{[11]}$. 富营养化波动发展与高强 度治理逆势互动的态势彰显了太湖生态环境治理的复杂性与艰巨性, 也成为国际湖沼学研究的热点与难题. 本文尝试在分析和反思近年太湖治理经验的基础上, 分析浅水湖泊富营养化久治难愈的关键因素, 阐明大 型浅水湖泊湖沼学基础理论的研究进展, 厘清存在的问题与不足, 梳理我国浅水湖泊湖沼学的发展方向, 并 提出以太湖为代表的大型富营养化浅水湖泊综合治理的未来之路.

\section{1 蓝藻水华成因机制与太湖 10 年治理实践反思}

\section{1 流域外源营养盐负荷居高不下}

太湖流域自 2007 年以来经过了 10 余年高强度治理,特别是大规模控源截污措施实施后,进人太湖的外 源营养盐负荷理应减少. 然而, 水利部太湖流域管理局的数据表明, 2008-2018 年多年平均太湖外源输人的 总氮约为 4 万 5 万 $\mathrm{t}$, 总磷约为 $2000 \mathrm{t}$, 与 2007 年水危机发生前相比并没有明显减少. 是什么原因导致太湖 外源污染负荷居高不下?

其一, 流域整体用水量增加造成营养盐入湖量增加. 根据水利部门的监测 ${ }^{[12]}, 2007$ 年前后每年进人太 湖的水量约为 70 亿 $\mathrm{m}^{3}$, 太湖换水周期大约为 260 天, 现在的年来水量约为 100 亿 150 亿 $\mathrm{m}^{3}$, 平均增量超过 $60 \%$, 换水周期则缩短至不足 150 天. 这个增量中的很大一部分并非天然降雨, 而是通过长江引水进入城镇 给排水循环系统, 经城镇使用后再通过污水处理厂排放进人河流及湖泊. 因此, 尽管排放的废水中污染物浓 度有所下降, 但流域内总水量增加、水循环加快的效应却使总污染负荷下降有限. 而且, 由于我国一级 A 排 放标准的总氮浓度为 $10 \sim 15 \mathrm{mg} / \mathrm{L}$, 总磷浓度为 $0.3 \sim 0.5 \mathrm{mg} / \mathrm{L}$, 排放出来的水中氮、磷浓度仍然远高于太湖 水体的氮、磷浓度.

其二,太湖流域分散而复杂的面源污染,包括农村居民生活污水、乡镇企业废水、农业生产污水、养殖废 水等, 仍未能得到有效的收集和处理. 对于这些数量分散、浓度较低的污染源, 因收集和集中处理成本较大, 国内外通用的办法是用湿地或者水塘等进行拦截和滞留. 按照湿地滞纳磷能力为 $1 \mathrm{~g} /\left(\mathrm{m}^{2} \cdot \mathrm{a}\right)^{[13]}$ 进行计算, 假设一半左右的磷是来自面源污染, 太湖流域大约需要 $1000 \mathrm{~km}^{2}$ 的湿地或者水塘. 目前仅仅恢复了环湖湿 地约 $100 \mathrm{~km}^{2}$, 显然远远不能满足需求. 正是面源污染治理的滞后, 使得太湖流域一旦遇到降水丰沛的年份, 人湖负荷即会显著增加. 如 2016 年太湖流域水量偏丰, 人湖水量超过 150 亿 $\mathrm{m}^{3}$, 总氮外源负荷输人量达到 了 5.35 万 $\mathrm{t}$, 总磷达到了 $2500 \mathrm{t}$ (来自水利部太湖流域管理局的数据), 较多年平均值分别高 $20 \%$ 和 $25 \%$. 而 迄今为止, 受太湖流域高速城市化和经济社会结构调整等影响, 这类面源污染的来源、负荷和贡献都不甚清 楚,这对于后面的控源截污、精准施策无疑是一个极大的挑战.

\section{2 浅水湖泊内源营养盐负荷的影响日趋显著}

湖泊内源污染根本上都是外源输人带来的. 外源营养盐人湖后很大比例沉淀、蓄积到底泥中, 转化成巨 
大的内源潜力. 太湖是一个大型浅水湖泊, 其内源污染机制、释放条件、贡献大小等与传统湖沼学中的深水 湖泊有很大不同 (图 1). 早期研究发现风浪可以导致沉积物大规模悬浮并释放大量营养盐, 其 “动态释放” 的强度远高于 “静态释放” ${ }^{[14-15]}$. 利用泥水柱状样在没有扰动的条件下测定的磷年释放量为 $899 \mathrm{t}$, 氮为 $10000 \mathrm{t}^{[16]}$; DGT 原位监测技术测定的太湖底泥年释放磷约为 $700 \mathrm{t}^{[17]}$. 基于这些观测结果, 可以确定太湖底 泥在静态条件下,释放的磷每年约为 700 900 $\mathrm{t}$, 接近外源输人的三分之一. 不过,这些方法都没有考虑底泥 再悬浮带来的大通量动态释放 ${ }^{[18]}$. 而且, 风浪导致的底泥悬浮与营养盐释放以颗粒态为主, 许多难以被藻 类吸收利用; 这些颗粒态营养盐在风浪过后又沉淀至湖底, 因而其生态系统贡献一直不清楚, 重要性在过往 也常常被忽略. 近年的蓝藻生长泥柱模拟实验及全湖调查发现, 上层 $3 \mathrm{~cm}$ 沉积物中生物可利用磷的总赋存 量高达 $5000 \mathrm{t}$ 以上 ${ }^{[19]}$. 野外 1 周年的原位底泥再悬浮观测表明, 没有水生植物覆盖的区域,再悬浮可以导致 水体总氮浓度增加 $0.34 \mathrm{mg} / \mathrm{L}$, 总磷浓度增加约 $0.05 \mathrm{mg} / \mathrm{L}^{[20]}$. 野外台风过程的观测证实, 风浪导致的沉积物 大量悬浮和营养盐释放, 有效促进了藻类生长并导致蓝藻水华暴发 ${ }^{[21-22]}$. 显然, 动力扰动导致的内源释放远 比我们想象的贡献大. 而频繁暴发的蓝藻水华还会通过提高水柱中 $\mathrm{pH}$ 值和活性有机物丰度、加强水一土界 面的还原环境、促进沉水植物消退等途径加剧内源污染. 因此, 浅水湖泊底泥内源释放的影响和重要性会随 着富营养化与蓝藻水华的加重逐渐凸显. 这在第 2 节还将专门予以论述.

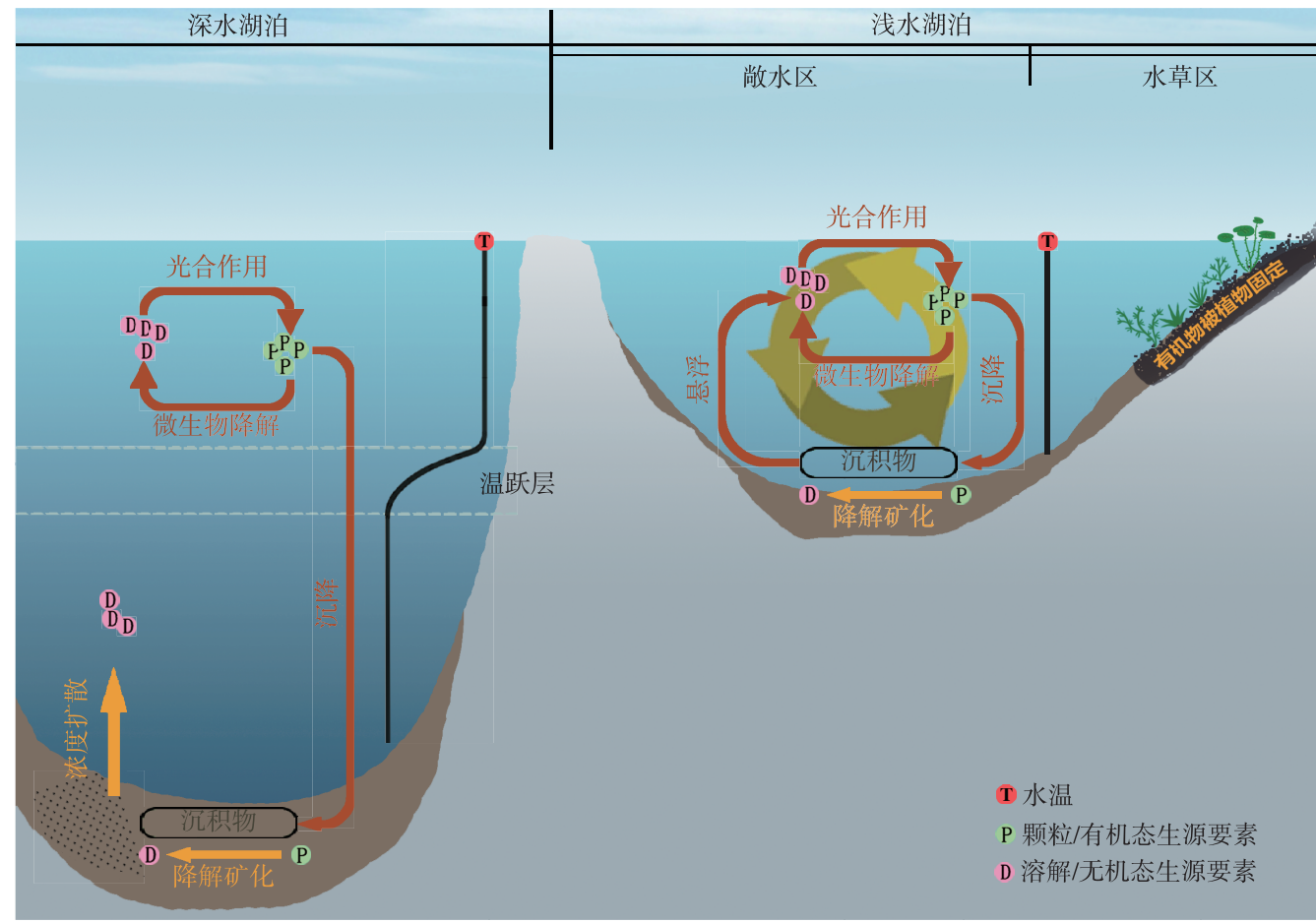

图 1 浅水湖泊与深水湖泊不同的营养盐循环模式

( 位于温带或寒温带地区的深水湖泊夏季存在温跃层, 上部混合层 (epilimnion) 与 下部滞水层 (hypolimnion) 很难发生交换, 许多颗粒态的有机物及营养盐通过沉淀到达湖底之后, 很难再回到上层水体;而浅水湖泊中,由于水深较小, 风浪湍流混合可以直接到达湖底, 水柱中的理化性质上下均匀一致,沉积至湖底的有机物和营养盐在风浪扰动情况下, 通过再悬浮进人上覆水中, 形成跨水一土界面的营养盐循环)

Fig. 1 Different nutrient cycle patterns in shallow and deep lakes

\section{3 气象水文条件变化对蓝藻水华的促进作用明显加强}

1.3.1 气候变化叠加富营养化对蓝藻水华的 “双驱动” 机制 全球变暖已经是不争的事实 ${ }^{[23]}$. 平均温度上 
升、风速下降、暴雨强度增加等气候变化对太湖富营养化与蓝藻水华的影响越来越突出 ${ }^{[24]}$. 温度上升会显 著加强蓝藻的优势地位、加重蓝藻水华 ${ }^{[25-27]}$, 气候变化的影响还存在短期 “记忆效应”, 即冬季的气候状况会 显著影响来年春季的浮游植物生物量及群落组成 ${ }^{[28]}$, 因而气候变暖在富营养化湖泊中的影响大于贫营养湖 泊,特别是对冬、春季生物活性极低甚至休眠的蓝藻而言 ${ }^{[29]}$. 长期监测结果显示, 长波散射辐射的显著增加 导致中国东部地区过去 50 年气温明显上升, 并且在蓝藻开始生长形成优势的春季上升最显著 ${ }^{[30-31]}$. 太湖地 区冬季温度接近藻类细胞分裂增殖的下限 $\left(5 \sim 6^{\circ} \mathrm{C}\right)^{[32]}$, 近年不断走高的冬、春季温度堣合高营养盐浓度, 导 致蓝藻水华发生的物候提前、频率增加和面积扩大 ${ }^{[33-35]}$. 据此, 我们提出了气候变暖与营养盐富集对蓝藻水 华的“双驱动”机制. 2007 年无锡水危机事件发生在 5 月,与 2006- 2007 年冬、春季节温度偏高诱发蓝藻水 华暴发加重进而污染取水口关系密切 ${ }^{[36]}$. 同样, 2016-2017 年和 2019-2020 年发生较早、强度极高的蓝藻 水华也是冬、春季温度异常增高所致. 2016-2017 年的暖冬不仅使 2016 年 12 月底出现了面积超过 $700 \mathrm{~km}^{2}$ 的蓝藻水华, 2017 年 5 月更出现了太湖自有遥感监测以来最大面积的蓝藻水华, 且影响一直延伸到 2017 年 的秋季. 2019 年测得的太湖水温日均值 $\left(19.6^{\circ} \mathrm{C}\right)$ 是 $2005-2019$ 年 15 年来的第 2 高值, 仅略低于 2007 年 $\left(20.2^{\circ} \mathrm{C}\right)$. 另外,近年来的持续增温强化了湖泊热力和溶解氧分层 ${ }^{[30]}$, 有利于水柱的稳定性结构和加强底部 的戻氧环境, 有利于喜欢稳定环境的蓝藻生长与水华暴发, 同时加剧了氮、磷的内源释放, 加大了内源污染 和蓝藻水华控制的难度.

伴随着全球变暖, 太湖流域的风速也在下降. 气象观测资料显示: 太湖地区近年来全年风速呈现下降趋 势, 主要表现为中高风速 $(>3 \mathrm{~m} / \mathrm{s})$ 出现频次显著下降, 每月日平均风速 $<3 \mathrm{~m} / \mathrm{s}$ 的最大持续天数显著增 加 ${ }^{[37]}$. 由于太湖污染严重的北部湖区底泥受风浪扰动的临界风速约为 $3 \sim 4 \mathrm{~m} / \mathrm{s}$, 因此太湖地区中高风速的 下降将有利于增加太湖水柱的稳定性 ${ }^{[37]}$; 同时, 风速下降使得风浪对湖底的侵蚀减弱, 低风速持续时间延长 会强化湖底间歇性缺氧和厌氧 ${ }^{[38]}$, 更有利于底泥营养盐释放,加重水体富营养化.

暴雨对陆地的冲刷会带来大量的悬浮物并随着地表径流流人湖水中, 造成大面积水体浑浊. 相较于正 常降雨, 暴雨径流更大的冲刷强度可能会使得蓄积在地表的营养盐更多地随径流进人湖泊, 甚至在一些贫 营养水体也会诱发短时间的藻类水华. 太湖的观测表明, 极端暴雨将大大增加水体颗粒物浓度, 影响范围可 达上百平方千米, 影响时间超过一周 ${ }^{[39]}$. 近 5 年来环境一号卫星数据显示, 强降水事件导致千岛湖悬浮物浓 度上升了 2 倍之多, 而由此引发的高浑浊区面积为 $41.3 \sim 148.1 \mathrm{~km}^{2}$, 均值为 $76.5 \mathrm{~km}^{2[40]}$. 长江中下游地区受 季风气候影响表现为典型的雨热同季, 而夏季蓝藻生长和水华暴发会消耗大量营养盐, 使得暴雨径流带来 的营养盐对蓝藻水华暴发强度的影响越来越重要 ${ }^{[41]}$. 随着全球气候变化, 未来极端暴雨事件频次和强度呈 增加的趋势,给面源污染和蓝藻水华控制都将带来更大的挑战 ${ }^{[42]}$.

1.3.2 大型浅水湖泊蓝藻水华暴发的物理机制 太湖蓝藻水华的时空动态变化较大, 在进行湖面观测时会感 觉到蓝澡水华有些“来无影、去无踪”. 传统监测和研究方法很难捕捉其发生发展的全过程, 影响了太湖蓝藻 水华暴发机制的研究. 最近的研究发现, 水动力条件对太湖蓝藻水华 “暴发” (水面聚集) 的影响是决定性 的,其物理机制主要体现在两方面:一是垂直方向的上浮作用,二是水平方向的输移和聚集 ${ }^{[43-44]}$.

野外肉眼可见的蓝藻水华主要以大群体藻类细胞团形态出现 ${ }^{[45]}$, 其细胞群体越大, 获得的浮力就越大, 更容易在风浪消失后快速上浮 ${ }^{[43]}$. 长期观测与实验研究发现, 蓝藻水华暴发的早期阶段主要受温度、光照 和营养盐的影响, 细胞不断分裂增殖使生物量逐步累积, 同时受环境中某些因子的胁迫而产生胞外多糖 (ex-

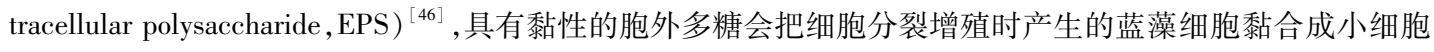
团 ${ }^{[47]}$; 当水柱中藻类细胞团聚集到一定的程度, 在湍流混合等作用下通过碰撞、黏合形成更多更大的细胞团 以获得更大的浮力 ${ }^{[43]}$, 上浮速度更快, 在动力扰动作用趋弱时快速上浮形成表面可见水华一一即水华 “暴 发”. 这一过程中, 不仅蓝藻细胞群体快速上浮受制于水动力条件的强弱变化, 其漂浮到水面后的细胞聚集 程度、扩散范围、空间分布、迁移走向以及最后的堆积均受制于水动力决定的水流辐合辐散状态 ${ }^{[43-44,48]}$. 在 大型富营养化浅水湖泊中, 风场作用下的风生流与散度场空间分布不均匀是导致蓝藻水华空间异质性较大 的主要因素. 正是太湖多变的风场, 使得辐合区和辐散区的时空分布不断变化,造成太湖蓝藻水华在短时间 尺度内的高度时空分异.

通过野外多点布设湖流和波浪监测设备, 开展同步原位高频观测结合频谱分析等, 揭示了太湖风生流 
复杂多变的机制 ${ }^{[49]}$. 虽然太湖的平均湖流不大 (平均约为 $10 \mathrm{~cm} / \mathrm{s}$ ), 但流场受到多种风场及外力作用的影 响,包括地球自转力 (科氏力)、湖陆温差导致的湖陆风、季节性的夏季风与冬季风以及风涌水引起的震荡内 波和湖底的摩擦阻力等. 在小风速条件下, 这些强度相近的驱动力作用于湖体, 导致湖流杂乱多变; 当风速 较大 (如台风过境) 时, 风的驱动力占主导, 整个水柱受风的拖曳作用向下风口输移而呈现一致的变化. 而夏 季盛行的东南风, 使得表层流场呈现东南至西北的流场特征, 导致蓝藻水华易于在太湖西北部堆积 ${ }^{[49]}$. 湖 流对营养盐的水平输送主要影响氮, 对磷的影响较小. 从太湖表层沉积物中氮、磷含量沿着河口到湖心的变 化梯度可以发现, 外源输人磷的输送距离距河口仅数千米, 对氮的输送距离可以达到数十千米, 甚至到湖心 地区 ${ }^{[48,50]}$. 同时, 垂直方向上的动力输送主要来自波浪作用而非湖流影响. 波浪引起的剪切力贡献了 $70 \%$ 的 沉积物再悬浮, 当风速大于 $6.5 \mathrm{~m} / \mathrm{s}$ 时, 沉积物将发生大规模悬浮 ${ }^{[15,51]}$. 当波长水深比 $>3$ 时, 沉积物发生快 速侵蚀和底泥大规模悬浮, 浊度升高 ${ }^{[38]}$, 诱发内源污染的脉冲式释放, 促进藻类生长和蓝藻水华暴发.

\section{2 大型浅水湖泊富营养化的生态效应与反馈作用}

大型浅水湖泊富营养化的长期持续会带来湖泊环境与生态系统的一系列变化,包括蓝藻水华 (或者其 他藻类水华) 频繁暴发 ${ }^{[52-53]}$ 、透明度下降 ${ }^{[54]}$ 、水柱中活性有机物丰度增加 ${ }^{[55]}$ 、湖泊戻氧的范围和频率增

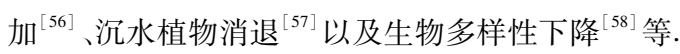

\section{1 富营养化水体的高效营养盐循环效应}

湖泊生态系统响应与富营养化的直接表征之一就是蓝藻水华的暴发. 前文已经说明, 太湖蓝藻面积及 叶绿素 $a$ 浓度在最近均呈现增加的态势, 而且水华的反弹幅度超过了营养盐, 如 2017 年总磷浓度较多年平 均值只增加了 $31 \%$, 而叶绿素 $a$ 浓度却增加了 79\%, 这中间显然有其他机制放大了蓝藻水华强度. 富营养水 体蓝藻水华频繁暴发导致的营养盐高效循环反馈机制是十分关键的.

前文 1.2 节谈及浅水湖泊内源污染时已经强调了蓝藻水华频繁暴发会使水柱中有机物丰度持续偏 高 ${ }^{[55,59]}$, 造成水体中异养细菌数量增加 1 2 个数量级、活性增强 $3 \sim 8$ 倍 ${ }^{\left[{ }^{60]}\right.}$, 而微生物的降解矿化会促进死 亡藻体及其伴生的其他活性有机物迅速降解, 成为水体中营养盐矿化再生 “热点” [55,59,61-62] “ “热点” 效应使 营养盐从有机态向无机态转化的周期由 1 2 周缩减至 $4 \sim 10 \mathrm{~h}$ (水温 $25^{\circ} \mathrm{C}$ 条件下) ${ }^{[60]}$, 快速高效地补充和供 给水体中蓝藻水华生长. 同时, 微生物参与藻类颗粒物的降解与矿化, 又使得水一沉积物体系里的溶解氧浓 度迅速下降 ${ }^{[56]}$, 加重水底戻氧情况 ${ }^{[37]}$, 诱发底泥中原先处于固化或钝化状态的磷活化释放进人上覆水, 促 进藻类生长和蓝藻水华暴发, 形成厌氧驱动的营养盐循环 ${ }^{[63]}$.

蓝藻水华暴发还会导致水体理化特性的改变. 太湖站最新观测数据显示, 太湖梅梁湾 $\mathrm{pH}$ 值有逐渐升高 的趋势, 原因在于蓝藻水华的频繁暴发及其范围的扩大, 使得水柱中光合作用增强、 $\mathrm{pH}$ 值升高 (图 2), 导致 底泥中蓄积的磷活化析出, 并随底泥的频繁再悬浮而大量释放进人上覆水体. 而浅水湖泊水深较浅的特点 容易使水柱中的 $\mathrm{pH}$ 值变化影响到湖底, 加重底泥内源污染问题. 由此, 形成了富营养化水体“藻类水华暴 发一活性有机物增加一溶解氧浓度降低一厌氧环境下营养盐释放一藻类水华再次暴发” 的恶性循环 ${ }^{[64]}$, 以及 “藻类水华暴发一 $\mathrm{pH}$ 值升高一无机磷活化释放一藻类水华加重” 的循环模式. 两种模式都会加剧沉积物中磷 的释放, 强化浅水湖泊内源污染的贡献,形成营养盐的高效循环反馈机制.

\section{2 浅水湖泊生态系统结构与功能对蓝藻水华的响应与反馈}

研究发现, 随着蓝藻水华的持续发生与发展, 湖泊中浮游动物日渐小型化, 对蓝藻的控制能力下降, 下 行效应减弱,有利于蓝藻水华的维持 ${ }^{[65]}$. 当温度持续偏高、风浪偏弱时, 这些聚集的蓝藻水华很快就会腐烂 分解, 造成异味、恶臭, 甚至形成“湖泛” ${ }^{[66]}$, 再释放出大量的营养盐参与循环 ${ }^{[67-68]}$, 导致蓝藻水华暴发的频 率增加, 形成与正常营养状态湖泊中明显不同的高效营养盐循环过程. 如图 3 所示, 正常湖泊中营养盐循环 过程是从初级生产者 (藻类、水生植物等) 到消费者 (浮游动物、游泳生物等), 连同其排泄物等都需经过分 解者微生物的降解矿化, 再转化为无机的氮、磷等营养盐, 被初级生产者吸收利用; 而富营养化湖泊中藻类 成为主要的初级生产者, 大量的藻类无法被浮游动物等捕食, 而是直接经过分解者微生物降解矿化快速转 化为无机的营养盐, 被藻类等初级生产者吸收利用. 富营养水体中营养盐在食物链中传递的过程缩短, 促进 了水柱中营养盐在藻类一水体间以及有机和无机态之间快速高效地转化循环. 


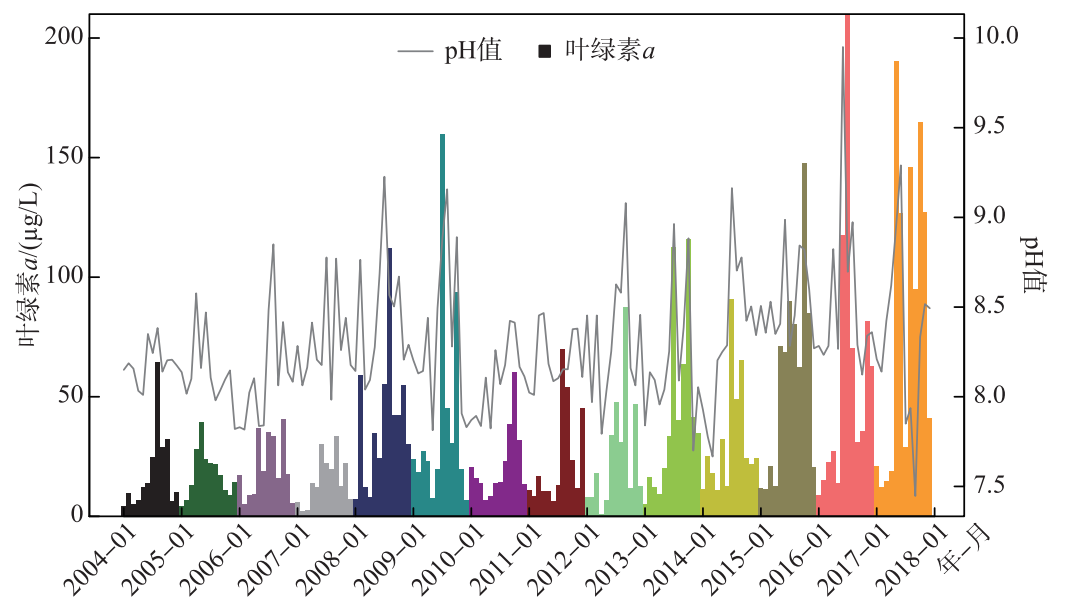

图 2 太湖梅梁湾逐月监测的水体 $\mathrm{pH}$ 值与叶绿素 $a$ 浓度的关系

Fig.2 Relationships between monthly $\mathrm{pH}$ and chlorophyll- $a$ concentration in water of Meiliang Bay in Lake Taihu

(a)

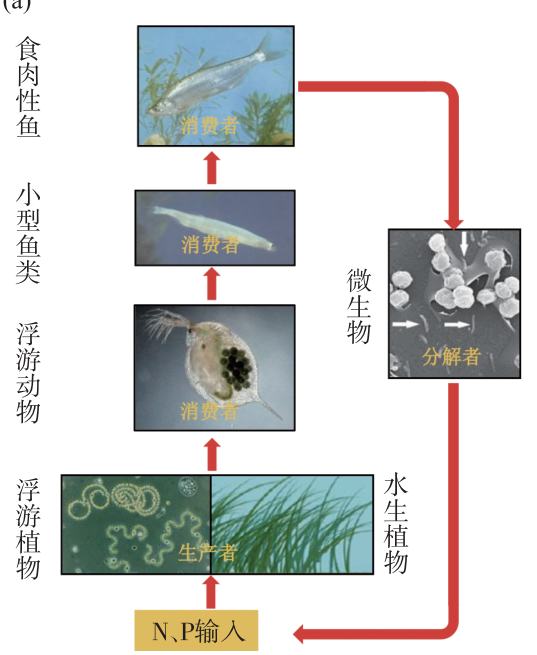

(b)

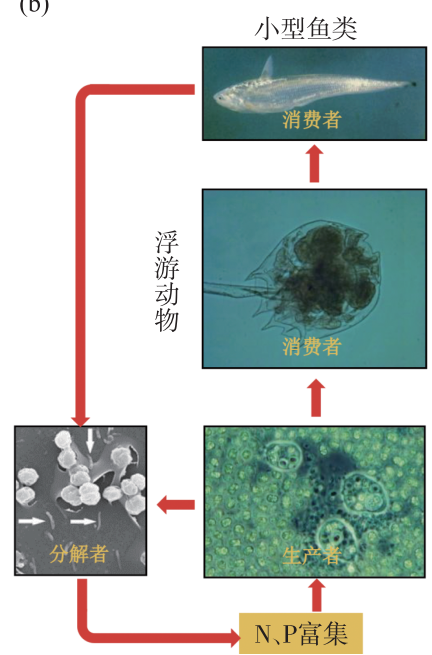

图 3 正常湖泊 (a) 与富营养化湖泊 (b) 营养盐循环途径的差异

Fig.3 Difference of nutrient cycle between normal (a) and eutrophic (b) lakes

另一方面, 模拟实验和 DGT 技术原位监测发现蓝藻水华堆积腐烂会造成沉积物表层极度缺氧,促进沉 积物向水体释放大量营养盐 ${ }^{[17,67-68]}$; 同时, 蓝藻水华的持续频繁暴发会不断加强水体营养盐的高效循环利 用 ${ }^{[59,61-62,67-68]}$. 此外, 光照强度是随着深度增加而减小的, 浅水湖泊中光照条件的影响就会更显著, 但蓝藻由 于具有伪空胞, 能够利用自身浮力到达水面从而获得更多光照, 更容易获得生存竞争优势, 形成水华, 聚集 于表层遮蔽光线; 而且, 蓝藻水华较为严重的水体会更加混浊, 造成水体透明度显著下降, 湖泊下层和底部 光照不足, 影响水生植物正常的光合作用和生长条件. 它们的共同作用不断地强化着湖泊生态系统退化, 加 剧富营养化和蓝藻水华的正反馈效应.

\section{3 草型生态系统退化与藻型生态系统扩张}

湖泊富营养化的另外一个显著效应是沉水植物消退和草型生态系统退化 ${ }^{[57,69]}$. 蓝藻水华的暴发及浅 水湖泊频繁风浪扰动诱导的沉积物再悬浮造成水柱中颗粒物丰度显著增加, 是水下光辐射衰减的决定性因 
素 ${ }^{[70-71]}$; 而富营养化导致的水柱浮游植物、附着生物和有机颗粒物增加, 会进一步恶化水下光环境并遏制水 生植物生长, 最终导致浅水湖泊沉水植被退化 ${ }^{[72]}$. 对太湖的研究表明, 营养盐浓度和透明度与水深的比值 对水生植被覆盖的决定作用超过 60\%, 成为草型、藻型生态系统转化的关键指标, 由此提出了营养盐富集和 水下光环境恶化共同驱动草型生态系统退化的作用机理 ${ }^{[57,73]}$. 据调查, 1960 年太湖的水生植物种类有 66 种, 隶属 48 属 29 科, 沉水植物面积约 $530 \mathrm{~km}^{2}$, 除东太湖和西太湖沿岸带, 五里湖等其他湖区亦有大面积分 布, 优势种为马来眼子菜 (Potamogeton malaianus) ${ }^{[74]}$; 至 1990s 中晚期, 太湖水生植物锐减到 17 种, 沉水植 物面积缩减至约 $400 \mathrm{~km}^{2}$ 且优势种演变为苦草 (Vallisneria natans) ${ }^{[75]}$. 太湖近 10 年水生植物多样性和分布 面积均有显著下降, 富营养化是重要的原因之一. 最近利用遥感监测发现, 不仅是太湖, 长江中下游及世界 各地都存在着不同程度的沉水植物消退趋势 ${ }^{[76-77]}$, 而沉水植物的消退又会加重沉积物中营养盐的释放, 加 剧湖泊富营养化. 没有水生植物覆盖的区域底泥释放较有水生植物覆盖的区域高 10 倍以上 ${ }^{[20]}$.气候变化 和富营养化交织在一起, 使得湖泊生态系统响应更为复杂. 过去 25 年间, 气候变暖叠加富营养化已经使太 湖的湖泊物理环境发生了显著变化, 表现为气温、水温和水位显著上升, 而风速和透明度则显著下降, 形成 和强化了有利于蓝藻生长、漂浮和聚集的藻型生境, 水生植物生长发育受到极大限制, 湖泊生境逐步由草型 生境向藻型生境转化 ${ }^{[69]}$.

\section{3 浅水湖泊湖沼学理论的发展与太湖治理的未来之路}

\section{1 浅水湖泊湖沼学对经典湖沼学的理论突破}

国际湖沼学于 20 世纪初发源于欧洲,绝大部分的经典理论都是基于对温带 (北半球中高纬度地区) 深 水湖泊的研究. 特别是生物的种类鉴定、组成结构的描述及其与理化环境 (温度、光照、营养盐等) 的关系分 析. 深水湖泊最显著的特点是在夏季存在热力分层, 上部混合层与下部滞水层之间的温度、溶解氧、浮游植 物和浮游动物等都有差异, 但环境条件相对稳定, 非常适合早期湖沼学对生物组成及其与环境因子关系以 描述性为主的研究. 浅水湖泊不同于深水湖泊, 其风驱动和水动力的混合作用常常多变而且不稳定, 夏季没 有明显的热力分层. 动力扰动导致的底泥悬浮、营养盐释放、溶解氧和热量均向下传输, 直接影响水下光照、 透明度、生物可利用的营养盐, 水柱乃至沉积物表层的氧化还原电位, 碳、氮和磷等的降解矿化, 更进一步影 响浮游植物的光合作用与初级生产率, 并且通过食物链的上行效应影响着整个生态系统的结构与功能. 而 且浅水湖泊中这些要素与过程不仅随着湖泊自身面积与水深变化, 也随着风场的时空变化而变化, 环境要 素空间分布格局的高度分异塑造了生态系统类型的多样, 其水体生物地球化学过程远较深水湖泊复杂并影 响深远 (图 1). 在太湖中, 水动力的时空分异特征结合水深、湖泊形态等地理环境特性, 导致其生态系统空 间上的异质性, 表现为东南部湖湾草型生态系统和西北部藻型生态系统两种截然不同的空间格局. 由于风 浪、温度、光照等都是地球科学领域的要素, 需要基于时间过程与空间格局来描述与研究, 而生态系统研究 的是结构与功能, 实现环境要素过程、格局研究与生态系统结构和功能研究的耦合, 正是浅水湖泊湖沼学研 究的特色所在,也是突破经典湖沼学的关键环节.

以太湖为代表的大型浅水湖泊研究是经典湖沼学研究匮乏的领域. 大型浅水湖泊对于富营养化与蓝藻 水华特别敏感, 全球湖泊的调查分析证实了蓝藻水华主要出现在浅水湖泊或者深水湖泊的浅湾 ${ }^{[78]}$; 全球范 围的大型湖泊也都呈现生态系统退化和生态服务功能下降的问题 ${ }^{[79]}$. 这一问题在我国尤其严重, 特别是长 江中下游地区及东部沿海地区的湖泊, 大都面临着与太湖类似的富营养化和蓝藻水华的威胁 ${ }^{[64]}$. 一方面绝 大部分湖泊都是浅水湖泊 ${ }^{[80]}$, 另一方面过去数十年各类型闸坝建设阻碍了湖泊与江河的自然联系, 导致湖 泊滞留的营养盐, 特别是磷的赋存量增加. 更为严峻的现实是, 快速发展经济、开发利用资源还是大多数地 方管理部门的主导思想, 因此迫切需要发展浅水湖泊湖沼学, 为我国湖泊生态环境治理与保护和资源的可 持续开发利用提供科学依据.

浅水湖泊湖沼学是多学科交叉融合的科学. 西方传统湖沼学研究起步于生物学, 逐步与生物地球化学 结合, 形成了今日的湖沼学体系. 但是, 与湖泊物理环境和过程的结合却远远不够. 我们从连接地学环境要 素与生态系统关系的营养盐循环人手, 以湖泊物理要素与过程为驱动, 通过 “抓过程、释机理” 的湖泊系统研 究思想 ${ }^{[81]}$, 综合运用水文水动力学、生物地球化学、沉积学、地理学和遥感 GIS 等研究方法与技术, 在大型浅 
水湖泊水动力特征、内源释放机制、富营养化与蓝藻水华暴发机理及其生态效应、湖泊生态恢复等方面取得 了一系列新的认识, 实现了跨学科的交叉融合. 未来浅水湖泊湖沼学的发展, 必须坚持多学科深度交叉融 合,探索浅水湖泊环境要素与过程对湖泊生态系统的影响与塑造,进而为太湖等大型浅水湖泊富营养化控 制提供科技支撑.

\section{2 浅水湖泊营养盐的生物地球化学特征及营养盐削减策略}

前文已述及, 深水湖泊与浅水湖泊水动力的影响差别非常显著. 湖泊中水动力导致的湍流混合决定了 向下输移热量与溶解氧等要素的深度和范围; 而水深、面积等地理要素决定了沉积物与湍流混合相互接触 及交换的范围与强度, 这种接触与混合对湖泊生物地球化学过程有着复杂深远的影响, 也决定了深水湖泊 与浅水湖泊的差异 (图 1). 深水湖库因相对静止的环境, 颗粒态的营养盐通过沉降作用沉至湖底, 很难再回 到上层混合层, 因此脱磷效率较高; 与之相反, 水体越浅, 风浪导致的兼氧条件越好, 富营养化带来的丰富的 硝态氮以及藻类水华暴发形成的较高活性、较大丰度的有机物都使得浅水湖泊反硝化程度越高, 氮的去除 能力越强 ${ }^{[46]}$. 根据 2018 年夏季江淮中下游湖库的调查结果, 大型浅水湖泊的总磷浓度明显高于深水湖库, 均值相差将近 20 倍, 充分表明深水、浅水湖库中磷沉降效率的差异; 同时, 叶绿素 $a$ 与水体总氮浓度在深水 湖库中没有明显关系, 在浅水湖泊中则表现出显著相关性 ${ }^{[48]}$. 深水、浅水湖泊中营养盐生物地球化学过程 的不同特性, 使得其浮游植物生长受到的营养盐限制不同, 而进一步影响水体营养状态, 因此, 富营养化与 蓝藻水华控制必须根据深水、浅水湖泊特点开展有针对性的研究和实施科学适用的策略.

20 世纪在著名的加拿大 227 号实验湖泊中进行的营养盐添加试验, 解决了经典湖沼学争论不休的湖泊 富营养化取决于元素碳、氮还是磷的问题 ${ }^{[82-84]}$,形成了以控磷为主的湖泊富营养化控制理论基础, 在国际湖 泊治理实践中也有许多成功的案例 ${ }^{[85]}$. 但是, 这些湖泊以深水富营养化湖泊为主, 许多大型富营养化浅水
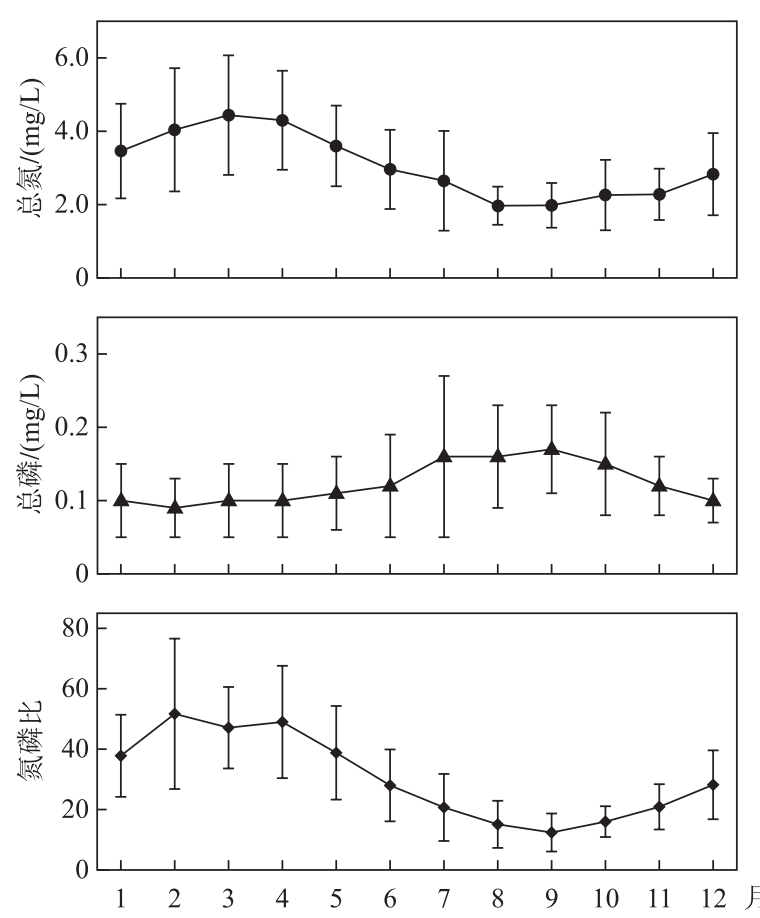

图 4 太湖梅梁湾水体多年平均逐月总氮、 总磷和氮磷质量比

Fig.4 The average monthly total nitrogen ( TN), total phosphorus ( TP) and TN:TP (mass ratio) in water of Meiliang Bay in Lake Taihu
湖泊或浅水湖湾治理成效并不明显, 特别是近 年来蓝藻水华问题出现反复的水体, 如美国五 大湖之一的 Erie 湖西部水域 ${ }^{[86]}$ 、美国的 Okechobee 湖 $^{[87]}$ 、美国的 Winnebago 湖 $^{[88]}$ 、加拿大 的 Winnipeg 湖 ${ }^{[89]}$ 、美国/加拿大交界的 Champlain 湖 $^{[90]}$ 、欧洲的 Peipsi 湖 ${ }^{[91]}$ 和非洲的 Victoria 湖 $^{[92]}$ 等, 说明大型浅水湖泊或浅水湖 湾富营养化的治理并非想象的那样简单. 时至 今日, 什么才是科学合理的营养盐削减政策, 控制富营养化与蓝藻水华究竟是控磷为主还 是氮磷双控, 这些问题仍是国际湖沼学争议的 热点 ${ }^{[85,93]}$. 由于控氮的成本是控磷成本的 10 倍左右 ${ }^{[94]}$, 氮、磷控制策略的选择关系到各国 控制富营养化蓝藻水华的资金投人和治理效 益, 必须审慎进行.

太湖梅梁湾开展的系列营养盐添加试验 发现, 浮游植物生长在夏、秋季出现明显的氮 限制, 而磷限制则一直存在 ${ }^{[95]}$; 随着藻类水华 暴发, 脱氮效率提高, 太湖氮磷比可从春季的 40 50 下降到夏秋季的 10 20 (图 4), 出现 氮、磷双限现象. 因此, 太湖富营养化控制需要 氮、磷同时控制. 根据收集的全球文献及美国 与欧盟的湖泊调查数据分析发现, 世界范围内 磷限制湖泊广泛存在, 特别是深水湖泊; 而氮、 磷双限现象主要存在于富营养化的浅水湖泊 
或者大型水体的浅水湖湾. 为了更有效地遏制蓝藻生长和水华暴发, 需要区别浅水与深水湖泊, 采取氮、磷 双控或单独控磷的不同控制策略 ${ }^{[78]}$. 类似太湖这样的浅水富营养化湖泊需要在控磷基础上协同控氮, 加速 湖泊的恢复与水质改善.

\section{3 自然和人文科学相结合的湖泊一流域综合治理与保护}

湖泊富营养化治理, “管理是关键, 技术是支撑”. 太湖、巢湖和滇池治理中遇到的许多问题并非技术上 无法解决,而是由于管理中的困难和矛盾. 包括废水排放标准与水环境保护的水质标准不匹配; 由于缺乏准 确的污染物负荷通量及经济价值的确定而导致生态补偿难以推广; 污染源责任不清导致的利益分配与协调 机制缺失使得治理缺乏持久动力; 许多研发的治理技术因未考虑实施的成本与经济效益而难以落地和推广. 特别是我国大部分富营养化湖泊都处于人口稠密、经济较发达地区, 而对社会经济发展规模与环境承载力 之间关系研究的长期匮乏, 使得现有以自然科学研究为主体的科研团队, 难以为湖泊一流域综合治理与生态 环境保护提供更有针对性的理论指导. 这些内容都需要人文科学领域的科研人员和管理专家参与,共同研 究寻求答案.

从太湖的富营养化治理实践来看, 湖泊治理不能只局限于湖体. 湖泊富营养化“病症在湖里, 病根在岸 上”, 流域上自然变化和人类活动产生的各种物质, 最终都会进人湖泊, 影响湖泊的水环境和生态系统 ${ }^{[96]}$. 因此, 对湖泊生态环境的研究必须延伸到流域, 发展湖泊流域系统科学. 如对太湖氮、磷污染的认知长期存 在面源污染来源贡献不清的问题, 且至今尚未找到合适的方法, 湖泊流域系统科学的发展有望突破这一瓶 颈. 通过降水径流过程与下垫面特征变化的结合, 解决污染物迁移转化与下垫面空间上分化特征在不同尺 度上的耦合问题, 厘清氮、磷等元素输移 (物理输移、滞留、沉淀、人渗等过程) 及其转化 (吸收、吸附、解析、反 硝化等) 的影响,逐步解决不同来源污染物的贡献、通量等问题 ${ }^{[97-98]}$.

太湖的内源污染控制尚未引起高度重视. 虽然前期已经对太湖西北部重点污染区域进行了表层沉积物 的生态清淤, 但相应也出现了底泥堆场占地、水分难以沥干和次生污染等问题, 亟需针对不同区域内源污染 贡献、疏浚底泥后续处置与资源化利用等难题实施科研攻关. 同时, 在部分底泥淤积区域、人湖河口区域等 水域采取挖深的办法, 布设若干深槽或者深沟, 通过捕获流动的、富含有机物 (包括藻类残体等) 的颗粒态营 养盐, 特别是颗粒态磷, 减轻内源污染负荷.

湖体生态修复是湖泊富营养化治理的高级阶段, 特别是以沉水植物为主体的草型生态系统培育, 必须 在控源截污和生境改善的前提下进行才能取得良好效果. 基于以往在太湖开展的草型生态系统退化机制研 究和梅梁湾生态恢复工程试验等结果, 综合国内外文献报道的研究成果, 浅水湖泊沉水植物恢复的核心条 件有 4 点: (1) 氮、磷浓度需要控制在一定的阈值之下; (2) 水下光环境阈值为真光层深度与水深比值接近或 者大于 1 ; (3) 没有蓝藻水华的人侵; (4) 鱼类群落组成以食肉性为主, 以部分滤食性鱼类为辅. 相应地提出了 控制营养盐、降低水深、消除风浪、降低悬浮物浓度进而提高真光层深度与水深比值, 改善水下光环境和恢 复水生植物的湖泊生态恢复原理 ${ }^{[32,61]}$. 以此原理为指导, 要实现太湖草型生态系统的恢复, 需要快速改善和 优化太湖草型生境. 例如, 在沉水植物恢复的光环境调控方面, 可以在春季水生植被生长发育的关键时期, 通过降低水位 (保持水位 $3.1 \mathrm{~m}$ 左右) 满足水生植被萌发所需的水下光照条件; 同时, 在条件适宜的湖湾内, 通过消浪措施减少风浪扰动, 降低悬浮物浓度和提高水体透明度. 再者, 在生态恢复区的生态系统调控方 面, 通过放养食肉性鱼类, 减少草食性、底栖和杂食性鱼类, 增加食物链的下行效应, 控制藻类生物量, 提高 水体透明度, 保障沉水植物正常生长及草型生态系统的恢复. 从历史上看, 太湖具备恢复沉水植被条件的水 域不多, 主要位于东太湖、胥口湾等水域. 对于其他水域, 建议在滨岸带恢复以挺水植物为主的湖滨湿地, 拦 截来自陆地的污染物, 捕获来自湖区漂移的蓝藻水华, 维持现在环境状态为上.

不过,正如本文阐明的研究结果,无论削减外源还是内源污染负荷都是艰巨复杂的工程,近年气象水文 条件的变化又加重了湖泊富营养化, 而浅水湖泊水深浅、扰动强的自有特性强化了内源污染的效应, 加剧了 藻类水华的暴发. 因此, 在可以预见的较长时期内, 富营养化引发的蓝藻水华灾害对水生态系统和供水安全 的威胁仍将呈高发态势, 精准监测和预测预警是提升湖库蓝藻水华主动防控能力和保障饮用水安全的优选 方案. 这方面, 无论是技术原理还是技术本身, 都处于快速发展中. 在对太湖的研究中, 早期就在浅水湖泊水 动力研究基础上, 构建和发展了以水动力为核心的太湖水环境和蓝藻水华模拟模型 ${ }^{[99-100]}$. 近年来, 遥感反 
演、高频自动在线监测等多介质、全过程监控技术方法的运用, 进一步提升了模型的预测预警精度 ${ }^{[101-102]}$, 并 基于模型的运行构建了浅水湖泊生态环境模拟模型和蓝藻水华预测预警系统. 在模型的移植过程中, 同样 面临一系列理论与技术瓶颈, 可喜的是相关研究方兴未艾, 在洱海、千岛湖和三峡水库等重要水体开始探 索 ${ }^{[11]}$, 成为湖泊流域生态环境管理的有力工具, 具有广泛的发展前景.

\section{4 结语}

我国湖泊类型多样、地理区域特色鲜明, 从湖泊资源开发利用到湖泊生态环境保护和湖泊流域可持续 发展, 强烈的国家需求一直引导着我国湖泊学的发展方向, 也奠定了我国浅水湖泊研究在国际湖沼学研究 领域的前沿地位. 面向未来, 湖泊环境健康稳定是 “山水林田湖草” 生态文明建设国家需求的重要内容, 保护 湖泊、治理富营养化任重而道远. 这需要自然科学与人文科学研究相结合形成的科学氛围! 需要相关管理 部门与科研工作者的密切合作! 湖泊科研工作者应当走出象牙塔, 立足于国家社会经济现状, 积极拓展水动 力变化、湖体营养盐生物地球化学循环、生态系统效应与反馈以及湖泊水质水环境模拟预测等浅水湖泊特 色研究, 真正服务于湖泊富营养化综合治理与生态恢复, 为保护绿水青山做出贡献.

致谢: 感谢中国科学院太湖湖泊生态系统研究站提供太湖水质观测数据; 感谢邓建明、丁㑆设计绘制图件.

\section{5 参考文献}

[ 1 ] Qin BQ. Progress and prospect on the eco-environmental research of Lake Taihu. J Lake Sci, 2009, 21 (4): 445-455. DOI : 10.18307/2009.0401. [秦伯强. 太湖生态与环境若干问题的研究进展及其展望. 湖泊科学, 2009, 21 (4): 445-455.]

[ 2 ] Guo L. Doing battle with the green monster of Taihu Lake. Science, 2007, 317(5842) : 1166. DOI: 10.1126/science.317. 5842.1166.

[ 3 ] Qin BQ, Gao G, Hu WP et al. Reflections on the theory and practice of shallow lake ecosystem restoration. J Lake Sci. 2005, 17 (1) : 9-16. DOI: 10.18307/2005.0102. [秦伯强, 高光, 胡维平等. 浅水湖泊生态系统恢复的理论与实践 思考. 湖泊科学, 2005,17 (1) : 9-16.]

[ 4 ] Qin BQ. Lake eutrophication: Control countermeasures and recycling exploitation. Ecological Engineering, 2009, 35(11) : 1569-1573. DOI: 10.1016/j.ecoleng.2009.04.003.

[ 5 ] Qin BQ. A large-scale biological control experiment to improve water quality in eutrophic Lake Taihu, China. Lake and Reservoir Management, 2013, 29(1) : 33-46. DOI: 10.1080/10402381.2013.767867.

[ 6 ] Qin BQ, Yang LY, Chen FZ et al. Mechanism and control technology of lake eutrophication and its application. Chinese Science Bulletin, 2006, 51(16) : 1857-1866. [秦伯强, 杨柳燕, 陈非洲等. 湖泊富营养化发生机制与控制技术及其 应用. 科学通报, 2006, 51(16): 1857-1866.

[ 7 ] Qin BQ. Principles and approach for lake ecological restoration. Acta Ecologica Sinica , 2007, 27(11) : 4848-4858. [秦伯 强. 湖泊生态恢复的基本原理与实现. 生态学报, 2007, 27 (11) : 4848-4858. ]

[ 8 ] Qin BQ, Paerl HW, Brookes JD et al. Why Lake Taihu continues to be plagued with cyanobacterial blooms through 10 years (2007-2017) efforts. Science Bulletin, 2019, 64(6) : 354-356. DOI: 10.1016/j.scib.2019.02.008.

[ 9 ] Zhu GW, Qin BQ, Zhang YL et al. Variation and driving factors of nutrients and chlorophyll-a concentrations in northern region of Lake Taihu, China, 2005-2017. J Lake Sci, 2018, 30(2) : 279-295. DOI: 10.18307/2018.0201. [ 朱广伟, 秦伯强, 张运林等. 2005-2017 年北部太湖水体叶绿素 a 和营养盐变化及影响因素. 湖泊科学, 2018, 30(2): 279-295.]

[10] Zhu GW, Zou W, Guo CX et al. Long-term variations of phosphorus concentration and capacity in Lake Taihu, 20052018: Implications for future phosphorus reduction target management. J Lake Sci, 2020, 32(1) : 21-35. DOI: 10.18307/ 2020.0103. [ 朱广伟, 邹伟, 国超旋等. 太湖水体磷浓度与赋存量长期变化(2005-2018 年) 及其对未来磷控制目 标管理的启示. 湖泊科学, 2020, 32(1): 21-35.]

[11] Zhu GW, Shi K, Li W et al. Seasonal forecast method of cyanobacterial bloom intensity in eutrophic Lake Taihu, China. $J$ Lake Sci, 2020, 32(5) : 1421-1431. DOI: 10.18307/2020.0504. [ 朱广伟, 施坤, 李未等. 太湖蓝藻水华的年度情势 预测方法探讨. 湖泊科学, 2020, 32(5) : 1421-1431.] 
［12］Taihu Basin Authority (TBA) ed. The health status report of Taihu Lake, 2008. [太湖健康状况报告. 太湖流域管理局 水文局, 2008.

[13] Richardson CJ, Qian SS. Long-term phosphorus assimilative capacity in freshwater wetlands: A new paradigm for sustaining ecosystem structure and function. Environmental Science \& Technology, 1999, 33 ( 10 ): 1545-1551. DOI: 10. 1021/es980924a.

[14] Zhu GW, Qin BQ, Gao G. Direct evidence of phosphorus outbreak release from sediment to overlying water in a large shallow lake caused by strong wind wave disturbance. Chinese Science Bulletin, 2005, 50 (6) : 577-582. DOI: 10. 1360/04wd0083.

[15] Qin BQ, Hu WP, Gao G et al. Dynamics of sediment resuspension and the conceptual schema of nutrient release in the large shallow Lake Taihu, China. Chinese Science Bulletin, 2004, 49(1) : 54-64. DOI: 10.1360/03wd0174.

[16] Qin BQ, Zhu GW, Zhang L et al. Estimation of internal nutrient release in large shallow Lake Taihu, China. Science in China: Series D, 2006, 49(1): 38-50.

[17] Ding SM, Chen MS, Gong MD et al. Internal phosphorus loading from sediments causes seasonal nitrogen limitation for harmful algal blooms. Science of the Total Environment, 2018, 625: 872-884. DOI: 10.1016/j.scitotenv.2017.12.348.

[ 18 ] Hu KM, Wang S, Pang Y. Suspension-sedimentation of sediment and release amount of internal load in Lake Taihu. J Lake $S c i, 2014,26$ (2) : 191-199. DOI: 10.18307/2014.0204. [ 胡开明, 王水, 逢勇. 太湖不同湖区底泥悬浮沉降规律研 究及内源释放量估算. 湖泊科学, 2014, 26(2) : 191-199.]

[19] Zhu MY, Zhu GW, Li W et al. Estimation of the algal-available phosphorus pool in sediments of a large, shallow eutrophic lake (Taihu, China) using profiled SMT fractional analysis. Environmental Pollution, 2013, 173: 216-223. DOI: 10. 1016/j.envpol.2012.10.016.

[20] Zhu MY, Zhu GW, Nurminen L et al. The influence of macrophytes on sediment resuspension and the effect of associated nutrients in a shallow and large lake (lake Taihu, China). PLoS ONE, 2015, 10(6) : e0127915. DOI: 10.1371/journal. pone.0127915.

[21] Ding YQ, Qin BQ, Zhu GW et al. Effects of typhoon Morakot on a large shallow lake ecosystem, Lake Taihu, China. Ecohydrology, 2012, 5(6) : 798-807. DOI: 10.1002/eco.270.

[22] Zhu MY, Paerl HW, Zhu GW et al. The role of tropical cyclones in stimulating cyanobacterial (Microcystis spp.) blooms in hypertrophic Lake Taihu, China. Harmful Algae, 2014, 39: 310-321. DOI: 10.1016/j.hal.2014.09.003.

[23] Cao LJ, Yan ZW, Zhao P et al. Climatic warming in China during 1901-2015 based on an extended dataset of instrumental temperature records. Environmental Research Letters, 2017, 12(6) : 064005. DOI : 10.1088/1748-9326/aa68e8.

[24] Deng JM, Qin BQ. A review on studies of effects of climate change on phytoplankton in freshwater systems. J Lake Sci, 2015, 27 (1) : 1-10. DOI: 10.18307/2015.0101. [邓建明, 秦伯强. 全球变暖对淡水湖泊浮游植物影响研究进展. 湖泊科学, $2015,27(1): 1-10$. ]

[25] Rigosi A, Carey CC, Ibelings BW et al. The interaction between climate warming and eutrophication to promote cyanobacteria is dependent on trophic state and varies among taxa. Limnology and Oceanography, 2014, 59(1) : 99-114. DOI: 10. 4319/lo.2014.59.1.0099.

[26] Paerl HW, Huisman J. Blooms like it hot. Science, 2008, 320(5872) : 57-58. DOI: 10.1126/science.1155398.

[27] Jöhnk KD, Huisman J, Sharples J et al. Summer heatwaves promote blooms of harmful cyanobacteria. Global Change Biolo$g y, 2008,14(3)$ : 495-512. DOI: 10.1111/j.1365-2486.2007.01510.x.

[28 ] Deng JM, Salmaso N, Jeppesen E et al. The relative importance of weather and nutrients determining phytoplankton assemblages differs between seasons in large Lake Taihu, China. Aquatic Sciences, 2019, 81(3) : 48. DOI: 10.1007/s00027019-0645-0.

[29] Deng JM, Qin BQ, Paerl HW et al. Earlier and warmer springs increase cyanobacterial (Microcystis spp.) blooms in subtropical Lake Taihu, China. Freshwater Biology, 2014, 59(5) : 1076-1085. DOI: 10.1111/fwb.12330.

[30] Zhang YL, Wu ZX, Liu ML et al. Thermal structure and response to long-term climatic changes in Lake Qiandaohu, a deep subtropical reservoir in China. Limnology and Oceanography, 2014, 59(4) : 1193-1202. DOI: 10.4319/lo.2014.59. 4.1193.

[31] Deng JM, Zhang YL, Qin BQ et al. Long-term changes in surface solar radiation and their effects on air temperature in the Shanghai region. International Journal of Climatology, 2015, 35(12) : 3385-3396. DOI: 10.1002/joc.4212. 
[32] Paerl HW, Hall NS, Calandrino ES. Controlling harmful cyanobacterial blooms in a world experiencing anthropogenic and climatic-induced change. Science of the Total Environment, 2011, 409(10) : 1739-1745. DOI: 10.1016/j.scitotenv.2011. 02.001 .

[33] Ma JR, Qin BQ, Paerl HW et al. The persistence of cyanobacterial (Microcystis spp.) blooms throughout winter in Lake Taihu, China. Limnology and Oceanography, 2016, 61(2) : 711-722. DOI: 10.1002//no.10246.

[34] Duan HT, Ma RH, Xu XF et al. Two-decade reconstruction of algal blooms in China's Lake Taihu. Environmental Science \& Technology, 2009, 43(10) : 3522-3528. DOI: 10.1021/es8031852.

[35] Shi K, Zhang YL, Zhang YB et al. Phenology of phytoplankton blooms in a trophic lake observed from long-term MODIS data. Environmental Science \& Technology, 2019, 53(5) : 2324-2331. DOI: 10.1021/acs.est.8b06887.

[36] Qin BQ, Zhu GW, Gao G et al. A drinking water crisis in Lake Taihu, China: Linkage to climatic variability and lake management. Environmental Management, 2010, 45(1) : 105-112. DOI: 10.1007/s00267-009-9393-6.

[37] Deng JM, Paerl HW, Qin BQ et al. Climatically-modulated decline in wind speed may strongly affect eutrophication in shallow lakes. Science of the Total Environment, 2018, 645: 1361-1370. DOI: 10.1016/j.scitotenv.2018.07.208.

[38] Wu TF, Timo H, Qin BQ et al. In-situ erosion of cohesive sediment in a large shallow lake experiencing long-term decline in wind speed. Journal of Hydrology, 2016, 539: 254-264. DOI: 10.1016/j.jhydrol.2016.05.021.

[39] Zhang YL, Shi K, Zhou YQ et al. Monitoring the river plume induced by heavy rainfall events in large, shallow, Lake Taihu using MODIS 250 m imagery. Remote Sensing of Environment, 2016, 173: 109-121. DOI: 10.1016/j. rse.2015. 11.020 .

[40] Zhang YB, Shi K, Zhang YL et al. River plume monitoring in a deep valley reservoir using HJ-1 A/B images. Journal of Hydrology, 2020, 587: 125031. DOI: 10.1016/j.jhydrol.2020.125031.

[41] Yang Z, Zhang M, Shi XL et al. Nutrient reduction magnifies the impact of extreme weather on cyanobacterial bloom formation in large shallow Lake Taihu (China). Water Research, 2016, 103: 302-310. DOI: 10.1016/j.watres.2016.07.047.

[42] Williams MR, King KW. Changing rainfall patterns over the western Lake Erie Basin (1975-2017) : Effects on tributary discharge and phosphorus load. Water Resources Research, 2020, 56(3) : e2019WR025985. DOI : 10.1029/2019WR025985.

[43] Qin BQ, Yang GJ, Ma JR et al. Spatiotemporal changes of cyanobacterial bloom in large shallow eutrophic lake Taihu, China. Frontiers in Microbiology, 2018, 9: 451. DOI: 10.3389/fmicb.2018.00451.

[44] Li W, Qin BQ. Dynamics of spatiotemporal heterogeneity of cyanobacterial blooms in large eutrophic Lake Taihu, China. Hydrobiologia , 2019, 833(1) : 81-93. DOI: 10.1007/s10750-019-3883-1.

[45] Wu XD, Kong FX. Effects of light and wind speed on the vertical distribution of Microcystis aeruginosa colonies of different sizes during a summer bloom. International Review of Hydrobiology, 2009, 94 ( 3 ): 258-266. DOI: 10. 1002/ iroh.200811141.

[46] Liu LZ, Huang Q, Qin BQ. Characteristics and roles of Microcystis extracellular polymeric substances ( EPS) in cyanobacterial blooms: A short review. Journal of Freshwater Ecology, 2018, 33 (1) : 183-193. DOI: 10. 1080/02705060. 2017.1391722.

[47] Xu HC, Cai HY, Yu GH et al. Insights into extracellular polymeric substances of cyanobacterium Microcystis aeruginosa using fractionation procedure and parallel factor analysis. Water Research, 2013, 47 (6) : 2005-2014. DOI: 10.1016/j. watres.2013.01.019.

[48] Wu TF, Qin BQ, Brookes JD et al. The influence of changes in wind patterns on the areal extension of surface cyanobacterial blooms in a large shallow lake in China. Science of the Total Environment, 2015, 518/519: 24-30. DOI: 10.1016/j. scitotenv.2015.02.090.

[49] Wu TF, Qin BQ, Ding WH et al. Field observation of different wind-induced basin-scale current field dynamics in a large, polymictic, eutrophic lake. Journal of Geophysical Research: Oceans, 2018, 123 ( 9): 6945-6961. DOI: 10. 1029/2018jc014040.

[50] Wu TF, Qin BQ, Brookes JD et al. Spatial distribution of sediment nitrogen and phosphorus in Lake Taihu from a hydrodynamics-induced transport perspective. Science of the Total Environment, 2019, 650: 1554-1565. DOI: 10. 1016/j. scitotenv.2018.09.145.

[51] Li YP, Tang CY, Wang JW et al. Effect of wave-current interactions on sediment resuspension in large shallow Lake Taihu, China. Environmental Science and Pollution Research, 2017, 24 (4) : 4029-4039. DOI: 10. 1007/s11356-016- 
8165-0.

[52] Chen Y, Qin B, Teubner K et al. Long-term dynamics of phytoplankton assemblages: Microcystis-domination in Lake Taihu, a large shallow lake in China. Journal of Plankton Research, 2003, 25(4) : 445-453. DOI: 10.1093/plankt/25. 4.445 .

[53] Paerl HW, Xu H, McCarthy MJ et al. Controlling harmful cyanobacterial blooms in a hyper-eutrophic lake (Lake Taihu, China): The need for a dual nutrient (N \& P) management strategy. Water Research, 2011, 45(5) : 1973-1983. DOI: 10.1016/j.watres.2010.09.018.

[54] Shi K, Zhang YL, Zhu GW et al. Deteriorating water clarity in shallow waters: Evidence from long term MODIS and in situ observations. International Journal of Applied Earth Observation and Geoinformation, 2018, 68: 287-297. DOI: 10.1016/j. jag.2017.12.015.

[55] Tang XM, Gao G, Qin BQ et al. Characterization of bacterial communities associated with organic aggregates in a large, shallow, eutrophic freshwater lake (Lake Taihu, China). Microbial Ecology, 2009, 58(2) : 307-322. DOI: 10.1007/ s00248-008-9482-8.

[56] Li HB, Xing P, Wu QL. Characterization of the bacterial community composition in a hypoxic zone induced by Microcystis blooms in Lake Taihu, China. FEMS Microbiology Ecology, 2012, 79(3) : 773-784. DOI: 10.1111/j.1574-6941.2011. 01262.x

[57] Dong BL, Qin BQ, Gao G et al. Submerged macrophyte communities and the controlling factors in large, shallow Lake Taihu (China) : Sediment distribution and water depth. Journal of Great Lakes Research, 2014, 40(3) : 646-655. DOI: 10.1016/j.jglr.2014.04.007.

[58 ] Cai YJ, Jiang JH, Zhang L et al. Simplification of macrozoobenthic assemblages related to anthropogenic eutrophication and cyanobacterial blooms in two large shallow subtropical lakes in China. Aquatic Ecosystem Health \& Management, 2012, 15 (1) : 81-91. DOI: 10.1080/14634988.2011.627017.

[59] Tang XM, Gao G, Chao JY et al. Dynamics of organic-aggregate-associated bacterial communities and related environmental factors in Lake Taihu, a large eutrophic shallow lake in China. Limnology and Oceanography, 2010, 55(2) : 469-480. DOI: $10.4319 / \mathrm{lo} .2010 .55 .2 .0469$.

[60] Gao G, Zhu GW, Qin BQ et al. Alkaline phosphatase activity and the phosphorus mineralization rate of Lake Taihu. Science in China: Series D, 2006, 49(S1) : 176-185. DOI: 10.1007/s11430-006-8117-5.

[61] Dai J, Chen D, Wu S et al. Dynamics of phosphorus and bacterial phoX genes during the decomposition of Microcystis blooms in a mesocosm. PLoS ONE, 2018, 13(5) : e0195205. DOI: 10.1371/journal.pone.0195205.

[62] Li HB, Xing P, Chen MJ et al. Short-term bacterial community composition dynamics in response to accumulation and breakdown of Microcystis blooms. Water Research, 2011, 45(4) : 1702-1710. DOI: 10.1016/j.watres.2010.11.011.

[63] Smith VH, Schindler DW. Eutrophication science: Where do we go from here? Trends in Ecology \& Evolution, 2009, 24 (4) : 201-207. DOI: 10.1016/j.tree.2008.11.009.

[64] Qin BQ, Gao G, Zhu GW et al. Lake eutrophication and its ecosystem response. Chinese Science Bulletin, 2013, 58(9) : 961-970. DOI: 10.1007/s11434-012-5560-x.

[65] Chen FZ, Chen MJ, Kong FX et al. Species-dependent effects of crustacean plankton on a microbial community, assessed using an enclosure experiment in Lake Taihu, China. Limnology and Oceanography, 2012, 57(6) : 1711-1720. DOI: 10. 4319/lo.2012.57.6.1711.

[66] Zhang YL, Shi K, Liu JJ et al. Meteorological and hydrological conditions driving the formation and disappearance of black blooms, an ecological disaster phenomena of eutrophication and algal blooms. Science of the Total Environment, 2016, 569/570: 1517-1529. DOI: 10.1016/j.scitotenv.2016.06.244.

[67] Zhu MY, Zhu GW, Zhao LL et al. Influence of algal bloom degradation on nutrient release at the sediment-water interface in Lake Taihu, China. Environmental Science and Pollution Research, 2013, 20(3) : 1803-1811. DOI: 10.1007/s11356012-1084-9.

[68] Zhang YL, van Dijk MA, Liu ML et al. The contribution of phytoplankton degradation to chromophoric dissolved organic matter (CDOM) in eutrophic shallow lakes: Field and experimental evidence. Water Research, 2009, 43 (18) : 46854697. DOI: 10.1016/j.watres.2009.07.024.

[69] Zhang YL, Qin BQ, Zhu GW et al. Profound changes in the physical environment of Lake Taihu from 25 years of long-term 
observations: Implications for algal bloom outbreaks and aquatic macrophyte loss. Water Resources Research, 2018, 54(7) : 4319-4331. DOI: 10.1029/2017wr022401.

[70] Liu XH, Zhang YL, Yin Y et al. Wind and submerged aquatic vegetation influence bio-optical properties in large shallow Lake Taihu, China. Journal of Geophysical Research: Biogeosciences, 2013, 118 ( 2): 713-727. DOI: 10. 1002/ jgrg. 20054.

[71] Shi K, Zhang YL, Zhu GW et al. Long-term remote monitoring of total suspended matter concentration in Lake Taihu using 250 m MODIS-Aqua data. Remote Sensing of Environment, 2015, 164: 43-56. DOI: 10.1016/j.rse.2015.02.029.

[72] Qin BQ, Song YZ, Gao G. The role of periphytes in the shift between macrophyte and phytoplankton dominated systems in a shallow, eutrophic lake (Lake Taihu, China). Science in China: Series C: Life Sciences, 2006, 49(6) : 597-602. DOI: $10.1007 / \mathrm{s} 11427-006-2025-\mathrm{y}$.

[73] Zhang YL, Liu XH, Qin BQ et al. Aquatic vegetation in response to increased eutrophication and degraded light climate in Eastern Lake Taihu: Implications for lake ecological restoration. Scientific Reports, 2016, 6: 23867. DOI: 10. 1038/ srep23867.

[74] Nanjing Institute of Geography, Chinese Academy of Sciences ed. Lake Taihu comprehensive investigation report. Beijing: Science Press, 1960. [中国科学院南京地理研究所. 太湖综合考察报告. 北京: 科学出版社, 1960.]

[75] Taihu Basin Authority, Ministry of Water Resources, Nanjing Institute of Geography \& Limnology, Chinese Academy of Sciences eds. Atlas of ecology and environment of the Taihu Lake. Bejing: Science Press, 2000. [水利部太湖流域管理 局, 中国科学院南京地理与湖泊研究所. 太湖生态环境地图集. 北京: 科学出版社, 2000.]

[76] Zhang YL, Jeppesen E, Liu XH et al. Global loss of aquatic vegetation in lakes. Earth-Science Reviews, 2017, 173: 259265. DOI: $10.1016 /$ j.earscirev.2017.08.013.

[77] Xu X, Zhang YB, Chen Q et al. Regime shifts in shallow lakes observed by remote sensing and the implications for management. Ecological Indicators, 2020, 113: 106285. DOI: 10.1016/j.ecolind.2020.106285.

[78] Qin BQ, Zhou J, Elser JJ et al. Water depth underpins the relative roles and fates of nitrogen and phosphorus in lakes. Environmental Science \& Technology, 2020, 54(6) : 3191-3198. DOI: 10.1021/acs.est.9b05858.

[79] Jenny JP, Anneville O, Arnaud F et al. Scientists' warning to humanity: Rapid degradation of the world's large lakes. Journal of Great Lakes Research, 2020. DOI: 10.1016/j.jglr.2020.05.006.

[ 80] Wang SM, Dou HS eds. Chinese lakes. Beijing: Science Press, 1998. [王苏民, 窦鸿身. 中国湖泊志. 北京: 科学出版 社, 1998.]

[ 81] Qin BQ, Hu WP, Chen WM et al eds. Process and mechanism of water environment evolution in Lake Taihu. Beijing: Science Press, 2004. [秦伯强, 胡维平, 陈伟民等. 太湖水环境演化过程与机理. 北京: 科学出版社, 2004.]

[82] Schindler DW. Eutrophication and recovery in experimental lakes: Implications for lake management. Science, 1974,184 (4139) : 897-899. DOI: 10.1126/science.184.4139.897.

[83] Schindler DW. Evolution of phosphorus limitation in lakes. Science, 1977, 195(4275) : 260-262. DOI: 10.1126/science. 195.4275.260.

[ 84] Stokstad E. Canada's experimental lakes. Science, 2008, 322 (5906) : 1316-1319. DOI: 10.1126/science.322.5906.1316.

[ 85] Schindler DW, Carpenter SR, Chapra SC et al. Reducing phosphorus to curb lake eutrophication is a success. Environmental Science \& Technology, 2016, 50(17) : 8923-8929. DOI: 10.1021/acs.est.6b02204.

[86] Bullerjahn GS, McKay RM, Davis TW et al. Global solutions to regional problems: Collecting global expertise to address the problem of harmful cyanobacterial blooms. A Lake Erie case study. Harmful Algae, 2016, 54: 223-238. DOI: 10. 1016/j.hal.2016.01.003.

[87] Rosen B, Davis T, Gobler C et al. Cyanobacteria of the 2016 Lake Okeechobee waterway harmful algal bloom. US Geological Survey Open-File Report, 2017, 1054(2017): 34.

[88] Beversdorf LJ, Weirich CA, Bartlett SL et al. Variable cyanobacterial toxin and metabolite profiles across six eutrophic lakes of differing physiochemical characteristics. Toxins, 2017, 9(2) : 62. DOI: 10.3390/toxins9020062.

[89] Ulrich AE, Malley DF, Watts PD. Lake Winnipeg Basin: Advocacy, challenges and progress for sustainable phosphorus and eutrophication control. Science of the Total Environment, 2016, 542: 1030-1039. DOI: 10.1016/j. scitotenv. 2015. 09.106.

[90] Fortin N, Munoz-Ramos V, Bird D et al. Toxic cyanobacterial bloom triggers in Missisquoi Bay, Lake Champlain, as de- 
termined by next-generation sequencing and quantitative PCR. Life, 2015, 5 ( 2 ) : 1346-1380. DOI: 10. 3390/ life5021346.

[91] Alikas K, Kangro K, Randoja R et al. Satellite-based products for monitoring optically complex inland waters in support of EU Water Framework Directive. International Journal of Remote Sensing, 2015, 36(17) : 4446-4468. DOI: 10.1080/ 01431161.2015.1083630.

[92 ] Ndlela LL, Oberholster PJ, van Wyk JH et al. An overview of cyanobacterial bloom occurrences and research in Africa over the last decade. Harmful Algae, 2016, 60: 11-26. DOI: 10.1016/j.hal.2016.10.001.

[93] Paerl HW, Scott JT, McCarthy MJ et al. It takes two to tango: When and where dual nutrient ( N \& P) reductions are needed to protect lakes and downstream ecosystems. Environmental Science \& Technology, 2016, 50 (20) : 10805-10813. DOI: $10.1021 /$ acs.est.6b02575.

[94] Schindler DW. The dilemma of controlling cultural eutrophication of lakes. Proceedings of the Royal Society B: Biological Sciences, 2012, 279(1746) : 4322-4333. DOI: 10.1098/rspb.2012.1032.

[95] Xu H, Paerl HW, Qin BQ et al. Nitrogen and phosphorus inputs control phytoplankton growth in eutrophic Lake Taihu, China. Limnology and Oceanography, 2010, 55(1) : 420-432. DOI: 10.4319/lo.2010.55.1.0420.

[96] Cardille JA, Carpenter SR, Coe MT et al. Carbon and water cycling in lake-rich landscapes: Landscape connections, lake hydrology, and biogeochemistry. Journal of Geophysical Research Atmospheres, 2007, 112 (G2) : G02031. DOI: 10. 1029/2006jg000200.

[97] Chen J, Zhu GW, Xu H et al. Influence of rainfall intensity on the nutrient loading from an inflowing river in the plain river network of the Taihu catchment. Environmental Science, 2019, 40(11) : 4924-4931. [陈洁, 朱广伟, 许海等. 不同雨 强对太湖河网区河道人湖营养盐负荷影响. 环境科学, 2019, 40(11) : 4924-4931.]

[98] Zhao Y, Xia Y, Ti C et al. Nitrogen removal capacity of the river network in a high nitrogen loading region. Environmental Science \& Technology, 2015, 49(3) : 1427-1435.

[99] Hu WP, Jørgensen SE, Zhang FB. A vertical-compressed three-dimensional ecological model in Lake Taihu, China. Ecological Modelling, 2006, 190(3/4) : 367-398. DOI: 10.1016/j.ecolmodel.2005.02.024.

[100] Li W, Qin BQ, Zhu GW. Forecasting short-term cyanobacterial blooms in Lake Taihu, China, using a coupled hydrodynamic-algal biomass model. Ecohydrology, 2014, 7(2) : 794-802. DOI: 10.1002/eco.1402.

[101] Qin BQ, Li W, Zhu GW et al. Cyanobacterial bloom management through integrated monitoring and forecasting in large shallow eutrophic Lake Taihu (China). Journal of Hazardous Materials, 2015, 287: 356-363. DOI: 10.1016/j.jhazmat. 2015.01.047.

[102] Li W, Qin BQ, Zhang YL et al. Numerical forecasting of short-term algae-induced black bloom in eutrophic shallow lake: A case study of Lake Taihu. J Lake Sci, 2016, 28(4) : 701-709. DOI: 10.18307/2016.0402. [李未, 秦伯强, 张运林等. 富营养化浅水湖泊藻源性湖泛的短期数值预报方法——太湖为例. 湖泊科学, 2016, 28(4) : 701-709.] 